\title{
Lithosphere mantle density beneath the Siberian craton
}

Cherepanova, Yulia; Artemieva, Irina

Published in:

GSA Abstracts with Programs

Publication date:

2016

Document version

Publisher's PDF, also known as Version of record

Document license:

CC BY

Citation for published version (APA):

Cherepanova, Y., \& Artemieva, I. (2016). Lithosphere mantle density beneath the Siberian craton. In GSA Abstracts with Programs (Vol. 16). [280146] 


\title{
Mantle density beneath the Siberian craton based on free board constrains
}

\author{
Yulia Cherepanova and Irina Artemieva \\ University of Copenhagen, Department of Geosciences and Natural Resource Management, Copenhagen, Denmark \\ (yc@ign.ku.dk)
}

We present the mantle density model of the Archean-Proterozoic Siberian Craton (SC). The density model is constrained by free-board (buoyancy) modeling (Lachenbruch and Morgan, 1990). The approach assumes isostatic compensation of the region, and is justified by the near-zero free-air gravity for most of the region, except for the flanking orogenic belts with high topography. Despite a relatively uniform topography of the SC (ca. $400 \mathrm{~m}$ for most of the region and reaching $700 \mathrm{~m}$ in the shields), the craton has a strongly heterogeneous crustal structure with large regional variations in Moho and average crustal Vp (Cherepanova et al., 2013) which reflects its complex tectonic evolution. Formed by amalgamation of several Archean terranes, the craton has been significantly affected by Proterozoic collisional and extensional events, the late- Proterozoic rifting at its margins, the Devonian rifting of the Vilyui rift, several pulses of kimberlite magmatism, and the Permo-Triassic trap basalt magmatism. The strong lateral and vertical heterogeneity of the lithospheric mantle has been documented so far in the studied of the mantle xenoliths from kimberlite pipes and in a limited number of geophysical studies.

Here we extend geophysical analysis of mantle compositional heterogeneity by evaluating mantle density structure and interpreting its regional variations in terms of mantle mg\#. We link regional large-amplitude variations in mantle depletion to the tectonic evolution of the craton and compare these results with geophysical models and petrologic data. We speculate on the origin of compositional heterogeneity of the lithospheric mantle, which is in overall agreement with results of a joint analysis of seismic and thermal data (Artemieva, 2009) and mantle xenolith studies which provide information on metasomatic enrichment of the depleted lithospheric mantle by the tectonic events.

The results indicate the heterogeneous structure of mantle density, with the average density of the entire craton of ca $3.36 \mathrm{~g} / \mathrm{cc}$, similar to the average density of the Archean mantle of the Kaapvaal craton (Jordan, 1979) and the global average for the Archean-Proterozoic mantle (Gaul et al., 1998). A significant density increase (to 3.38 -3.40 $\mathrm{g} / \mathrm{cc}$ ) is characteristic of the major basins of the SC (the Tunguska and the Viluy basins). The density values agree with data from mantle xenoliths (Griffin et al., 2005) which show metasomatic enrichment of the lithospheric mantle in the regions with the high mantle density. Low density compositional anomalies (density of 3.33-3.35 $\mathrm{g} / \mathrm{cc}$ ) are observed beneath the Archean terranes with the local minimum at the Anabar shield, where density is lower than reported for the Siberian xenoliths (e.g. Djomani et al., 2001). Our results demonstrate that kimberlite fields do not sample the most depleted cratonic mantle of the Siberian craton. 